\title{
Relative Abundance of the Prairie Long-tailed Weasel (Mustela frenata longicauda) in Southwestern Alberta
}

\author{
GARry E. HornBECK ${ }^{1,2}$ and DAN SOPROVICH ${ }^{3}$ \\ ${ }^{1}$ Wildlife \& Company Ltd., 312 Cedarille Crescent, SW, Calgary, Alberta T2W 2H7 Canada \\ ${ }^{2}$ Corresponding author; email: hornbeck@telusplanet.net \\ ${ }^{3}$ Bluestem Wildlife, 10 Parkdale Drive, Swan River, Manitoba R0L 1Z0 Canada
}

Hornbeck, Garry E., and Dan Soprovich. 2013. Relative abundance of the Prairie Long-tailed Weasel (Mustela frenata longicauda) in southwestern Alberta. Canadian Field-Naturalist 127(2): 131-137.

Prairie Long-tailed Weasels (Mustela frenata longicauda) were live-trapped during fall 2005, 2006, and 2007 at Pine Coulee Reservoir and during fall 2005, 2008, and 2010 at Twin Valley Reservoir in southwestern Alberta. Our objective was to estimate the relative abundance of the Long-tailed Weasel and to estimate the relative abundance of small mammal prey. Body size and capture rates are reported for Long-tailed Weasels, and we report capture rates of small mammals. Annual capture rates for Long-tailed Weasels at Pine Coulee Reservoir were $0.44,0.41$, and 0.50 individuals per 100 corrected trap-nights $(0.42,0.38$, and 0.48 individuals/100 trap-nights) in 2005, 2006, and 2007, respectively. No Long-tailed Weasels were captured at Twin Valley Reservoir. The probability of capturing zero Long-tailed Weasels at Twin Valley Reservoir was very low, assuming a true capture probability equivalent to that observed at Pine Coulee Reservoir. Deer Mice (Peromyscus maniculatus) were the most abundant small mammals captured in both project areas. Few shrews (Sorex spp.) and voles (Microtus spp.) were captured in either area.

Key Words: Mustela frenata longicauda; Prairie Long-tailed Weasel; capture rate; capture probability; relative abundance; Peromyscus maniculatus; Deer Mouse; Sorex; shrew; Microtus; vole; Alberta

Prairie Long-tailed Weasels (Mustela frenata longicauda) are known to exist across two thirds of Alberta in semi-urban areas, rural and agricultural areas, grasslands, parklands, the foothills of the Rocky Mountains, and montane forests (Smith 1993). Proulx and Drescher (1993) reported that the Long-tailed Weasel was present in the central and southern regions of the province, as reported in earlier decades (Soper 1964). However, the ecology of the Long-tailed Weasel in Alberta is poorly understood, as is generally true for this species across its range (Gehring and Swihart 2004; Richter and Schauber 2006; Hajduk 2008). The species is currently designated as May Be At Risk in Alberta (Alberta Sustainable Resource Development 2010*).

We investigated the relative abundance of the Longtailed Weasel on mitigation land surrounding two reservoirs in southern Alberta, the Pine Coulee Reservoir and the Twin Valley Reservoir, following the completion of the construction of the reservoirs. We also estimated the relative abundance of small mammals on these two mitigation sites in order to investigate the prey base. Mitigation land is a reserve of public land surrounding each water management project, intended to replace habitat lost and altered as a result of project development. Our overall goal was to determine whether Long-tailed Weasels were present at mitigation sites and to determine their relative abundance.

\section{Study Areas}

Pine Coulee Reservoir $\left(50^{\circ} 7^{\prime} \mathrm{N}, 113^{\circ} 44^{\prime} \mathrm{W}\right)$ and Twin Valley Reservoir $\left(50^{\circ} 14^{\prime} \mathrm{N}, 113^{\circ} 24^{\prime} \mathrm{W}\right)$ in southwestern Alberta are separated by about $30 \mathrm{~km}$ (Figure 1). Pine
Coulee Reservoir is an off-stream reservoir (elevation $1052.5 \mathrm{~m} ; 50600 \mathrm{~m}^{3}$ at full supply level; completed in 2000) which lies in the Foothills Fescue Natural Subregion, the highest elevation grassland sub-region in the province (Natural Regions Committee 2006*). Soils in the Foothills Fescue Natural Subregion are primarily Orthic Black Chernozem, reflecting moist, cool conditions. Reference vegetation in this area is Mountain Rough Fescue (Festuca campestris) and Idaho Fescue (Festuca idahoensis) with a diverse forb component.

Twin Valley Reservoir is an on-stream reservoir (elevation $964.5 \mathrm{~m} ; 60700 \mathrm{~m}^{3}$ at full supply level; completed in 2004) which lies within the drier and colder Mixedgrass Natural Subregion (Natural Regions Committee 2006*). Soils in this subregion are predominantly Orthic Dark Brown Chernozem, and reference vegetation is Blue Grama (Bouteloua gracilis), Needleand-Thread (Hesperostipa comata subsp. comata), and Northern Wheat Grass (Agropyron dasystachyum).

\section{Methods}

We conducted live trapping during the fall of 2005 at both Pine Coulee Reservoir and Twin Valley Reservoir (Table 1). Based on success at Pine Coulee Reservoir but not at Twin Valley Reservoir, we returned to Pine Coulee Reservoir with an expanded effort during fall 2006 and 2007. During fall 2008 and 2010, we returned to Twin Valley Reservoir with an expanded trapping effort. During 2010, we added 16 baited track tunnels and 8 live traps in a trapline along a fence separating mitigation land from cropland at Twin Valley Reservoir (Table 1). 

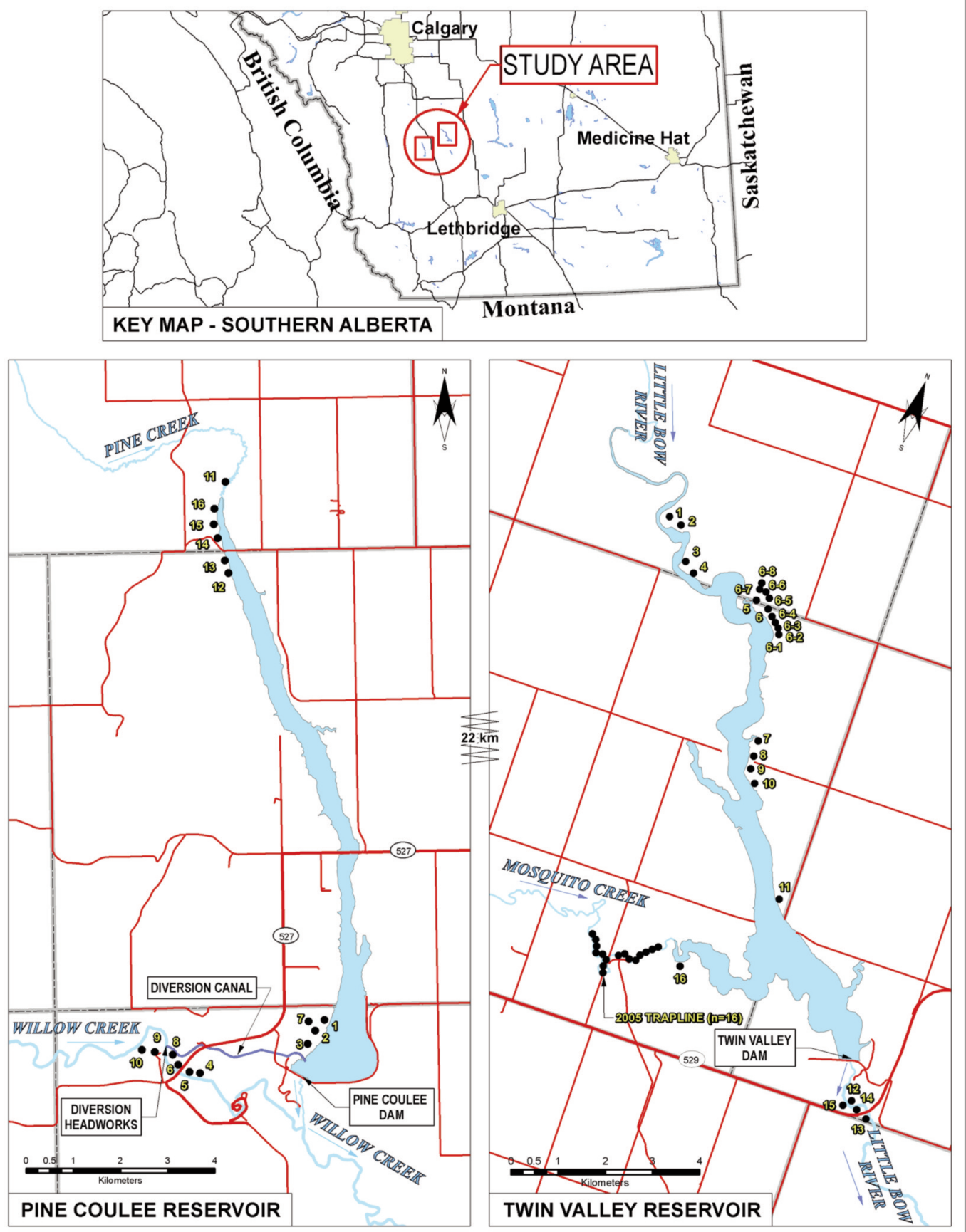

FiguRE 1. Pine Coulee project area (left) showing 16 trapping locations as operated between mid-October and late October 2007, and Twin Valley project area (right) showing 16 trapping locations and trapline as operated between midOctober and late October 2010. 
TABle 1. Prairie Long-tailed Weasel (Mustela frenata longicauda) trapping dates and effort (trap-nights and corrected trapnights) in southwestern Alberta at the Pine Coulee Reservoir project area in 2005, 2006, and 2007 and at the Twin Valley Reservoir project area in 2005, 2008, and 2010.

\begin{tabular}{|c|c|c|c|c|}
\hline \multirow[b]{2}{*}{ Year } & \multicolumn{2}{|c|}{ Pine Coulee Reservoir } & \multicolumn{2}{|c|}{ Twin Valley Reservoir } \\
\hline & Trapping dates & Trapping effort & Trapping dates & Trapping effort \\
\hline 2005 & 1 to 5 November & $\begin{array}{l}238 \text { trap-nights (189 corrected } \\
\text { trap-nights) (12 trap grids with } \\
\text { a total of } 48 \text { traps) }\end{array}$ & 8 to 12 November & $\begin{array}{l}200 \text { trap-nights (160 corrected } \\
\text { trap-nights) ( } 8 \text { trap grids with a } \\
\text { total of } 32 \text { traps and } 16 \text { traps in } \\
\text { trapline) }\end{array}$ \\
\hline 2006 & 12 to 24 October & $\begin{array}{l}752 \text { trap-nights ( } 626 \text { corrected } \\
\text { trap-nights) (15 trap grids with } \\
\text { a total of } 60 \text { traps })\end{array}$ & No fieldwork & \\
\hline 2007 & 10 to 22 October & $\begin{array}{l}794 \text { trap-nights ( } 716 \text { corrected } \\
\text { trap-nights) (16 trap grids with } \\
\text { a total of } 64 \text { traps) }\end{array}$ & No fieldwork & \\
\hline 2008 & & No fieldwork & 15 to 27 October & $\begin{array}{l}789 \text { trap-nights ( } 682 \text { corrected } \\
\text { trap-nights) (16 trap grids with } \\
\text { a total of } 64 \text { traps) }\end{array}$ \\
\hline 2010 & & No fieldwork & 15 to 27 October & $\begin{array}{l}927 \text { trap-nights ( } 787 \text { corrected } \\
\text { trap-nights) (16 trap grids with } \\
\text { a total of } 64 \text { traps and } 8 \text { traps } \\
\text { in trapline) }\end{array}$ \\
\hline
\end{tabular}

\section{Trapping and handling of Long-tailed Weasels}

We used Tru-Catch live traps constructed with a wire mesh steel frame (Tru-Catch Traps, Belle Fourche, South Dakota). Two trap sizes were used: Model \#18 $(46 \mathrm{~cm} \times 15 \mathrm{~cm} \times 18 \mathrm{~cm})$ and Model \#24 $(61 \mathrm{~cm} \times$ $20 \mathrm{~cm} \times 23 \mathrm{~cm})$. Trapped areas were chosen a priori from the largest contiguous tracts of available mitigation land, subject to the requirement for a wide distribution of traps but constrained by the need for reasonable access. Live traps were set out in a four-trap grid configuration, with $141 \mathrm{~m}$ between traps. At a few locations, traps were set closer to accommodate the edge of the reservoir or the edge of a pasture that contained cattle.

A single slice of commercial bacon was used for bait and food (25-30 g per slice) (Simms 1979; Robitaille and Raymond 1995). Bacon has a high fat and salt content, it is aromatic (mustelids have an acute sense of smell) (Merritt 2010), it doesn't spoil quickly, and it presents no infection-related health concerns to humans or wildlife (Schlexer 2008). Thinsulate microfibre $(15 \mathrm{~cm} \times 18 \mathrm{~cm})$ was placed in each live trap for bedding material.

Traps were checked daily, and regular maintenance was performed to maintain a cover of grass and woody material over each live trap, to adjust the bedding material, and to resupply bait. The number of trap-nights was corrected (corrected trap-nights) for traps sprung for any reason, following advice of King (1989), and a few occasions when traps were rendered inoperable by freezing rain ( 5 traps on 2 November 2005 and 10 traps on 17 October 2006, both at Pine Coulee Reservoir).

We also provide relative abundance based on total (uncorrected) trap-nights. Long-tailed Weasels were released from live traps into a capture net, and the net was twisted around the weasel for restraint. Body length was measured from the tip of the nose to the base of the tail using a steel pocket tape measure. The tail was measured from the body to the tip. Body weight was measured with an Avinet 1.0-kg spring scale (accurate to within $2 \mathrm{~g}$ ) (Avinet, Dryden, New York). Each Long-tailed Weasel was individually marked with red hair dye. The sex of the Long-tailed Weasels captured in 2007 was determined by visual inspection of the inguinal region (anal-genital separation), but this was not attempted during earlier captures. Long-tailed Weasels were released at the capture site. A Research Permit and Collection Licence was issued by Alberta Sustainable Resource Development.

\section{Traplines and track tunnels at Twin Valley Reservoir}

In 2005, in addition to live trap grids, 16 identical live traps were placed in linear sequence at $141-\mathrm{m}$ intervals along the north bank of Mosquito Creek entering Twin Valley Reservoir (Table 1). This site was chosen based on a location report of a Long-tailed Weasel by Golder Associates (1995*). In 2010, in addition to live trap grids, 8 live traps were placed in linear sequence at $141-\mathrm{m}$ intervals along a fenceline separating mitigation land from cropland at Twin Valley Reservoir near a chance observation of a Long-tailed Weasel in wheat stubble during fall 2008.

Track tunnels specifically designed for detection of weasels $(60 \mathrm{~cm} \times 10 \mathrm{~cm} \times 10 \mathrm{~cm})$ were deployed at Twin Valley Reservoir in 2010 as an additional detection device (King and Edgar 1977; Dilks et al. 1996). A track tunnel $(n=16)$ was randomly assigned to one of the live traps within each of the 16 trap grids, offset from the live trap by $10 \mathrm{~m}$ in a clockwise direction. 
TABle 2. Capture rates of Prairie Long-tailed Weasels (Mustela frenata longicauda) at Pine Coulee Reservoir during three consecutive years of fall live trapping, southwestern Alberta (trap-nights and corrected trap-nights).

\begin{tabular}{lcccc}
\hline \hline Trapping dates & $\begin{array}{c}\text { Number of } \\
\text { individuals } \\
\text { captured }\end{array}$ & $\begin{array}{c}\text { Capture rate } \\
\text { (number/100 corrected } \\
\text { trap-nights) }\end{array}$ & $\begin{array}{c}\text { Capture rate } \\
\text { (number/100 } \\
\text { trap-nights) }\end{array}$ & $\begin{array}{c}\text { Mean number } \\
\text { of individuals } \\
\text { captured/grid }\end{array}$ \\
\hline 1 to 5 November 2005 & 1 & 0.44 & 0.42 & 0.08 \\
12 to 24 October 2006 & 3 & 0.41 & 0.38 & 0.20 \\
10 to 22 October 2007 & 4 & 0.50 & 0.48 & 0.24 \\
\hline \hline
\end{tabular}

Track cards were inked in the centre with a $10 \mathrm{~cm} \times$ $10 \mathrm{~cm}$ square of ink that surrounded half a slice of bacon. Track cards were inspected daily for tracks and bait was replenished.

\section{Trapping small mammals}

A Victor mouse snap trap (Woodstream, Lititz, Pennsylvania, model no. M150CAN) was offset from each live trap by $10 \mathrm{~m}$, to capture mice, voles, and shrews. Snap traps were baited with peanut butter or peanut butter mixed with instant oat flakes (Beer 1964; Patric 1970) and replenished daily. We report small mammal capture rates on the basis of total number of trap-nights adjusted for lost traps, and we report corrected trap-nights (Nelson and Clark 1973). $F$ tests for variance and paired or non-paired $t$ tests, as indicated, were conducted using Excel 2003.

\section{Results}

Eight (8) Long-tailed Weasels were captured at Pine Coulee Reservoir (Table 2): one in 2005, three in 2006, and four in 2007. No Long-tailed Weasels were captured at Twin Valley Reservoir. At Pine Coulee Reservoir, Long-tailed Weasels were captured on six different trap grids (eight different individual trap sites) in three different locations around the reservoir: the riparian zone of Willow Creek, native pasture on the floodplain terrace adjacent to Willow Creek, dense nonnative grassland at the edge of heavily grazed pasture adjacent $(<100 \mathrm{~m})$ to a constructed wetland, and in native grassland/shrub with a mixture of agronomic species adjacent to the reservoir.

\section{Long-tailed Weasel body measurements}

The two females captured on 14 and 16 October at Pine Coulee Reservoir trap site 2E, \#1-07 and \#2-07, measured $38 \mathrm{~cm}$ total body length (body and tail) and $15 \mathrm{~cm}$ tail length, and were $170 \mathrm{~g}$ and $175 \mathrm{~g}$, respectively. The male captured on 17 October 2007 at Pine Coulee Reservoir trap site 4E, \#3-07, was $45 \mathrm{~cm}$ total body length and $19 \mathrm{~cm}$ tail length, and weighed $270 \mathrm{~g}$. The male captured on 22 October 2007 at Pine Coulee Reservoir site 3E, \#4-07, measured $41 \mathrm{~cm}$ total body length and $15 \mathrm{~cm}$ tail length, and weighed $245 \mathrm{~g}$. The largest Long-tailed Weasel we captured was \#3-06, on 23 October 2006 at Pine Coulee Reservoir site 11S. He measured $44 \mathrm{~cm}$ total body length and $16.5 \mathrm{~cm}$ tail length, and weighed $300 \mathrm{~g}$. Smith (1993) reported the average length for adult females as $37.9 \mathrm{~cm}$ and the average length for adult males as $43.8 \mathrm{~cm}$. The range of live weights for adult females in Alberta was 154.3 $\mathrm{g}$ to $242.6 \mathrm{~g}(n=11)$ and for adult males in Alberta was $242.3 \mathrm{~g}$ to $423.7 \mathrm{~g}(n=20)$ (Smith 1993).

\section{Long-tailed Weasel capture rates at Pine Coulee Reservoir}

The capture rate of individuals was similar between years: $0.44 / 100$ corrected trap-nights $(0.42 / 100$ trapnights) in 2005, 0.41/100 corrected trap-nights (0.38/ 100 trap-nights) in 2006, and 0.50/100 corrected trapnights (0.48/100 trap-nights) in 2007 (Table 2). The probability of capture per grid was $8.3 \%$ in 2005 (a Long-tailed Weasel was captured on 1 of 12 grids), $13.3 \%$ in 2006 (Long-tailed Weasels were captured on 2 of 15 grids), and $18.8 \%$ during 2007 (Long-tailed Weasels were captured on 3 of 16 grids). The probability increased to $35.7 \%$ ( 5 of 14 grids) when data from trap grids common to 2006 and 2007 were combined. This demonstrates the advantage of trapping for more than one year to gain an understanding of spatial distribution; an advantage also accrues respecting comparison of Long-tailed Weasels between the two project areas.

\section{Long-tailed Weasels at Twin Valley Reservoir}

No Long-tailed Weasels were captured at Twin Valley Reservoir, despite a known presence adjacent to the project area that was revealed by a chance observation of a Long-tailed Weasel on 17 October 2008 at a burrow in wheat stubble on day 3 of the 13-day trapping session. The chance observation was $295 \mathrm{~m}$ from the closest live trap near the edge of mitigation land.

We estimated the probability of not capturing a Long-tailed Weasel at Twin Valley Reservoir over two non-consecutive years (2008 and 2010) and assuming the same capture probability as at Pine Coulee Reservoir. Using a modification of Kery (2002), the probability of zero captures using 16 grids trapped for two years is $P=0.09 \%$. This low estimate of Type II Error (relevant to a conclusion that Long-tailed Weasels were not present when they were present at the frequency observed at Pine Coulee Reservoir) demonstrates the advantages of multiple years of sampling to better understand the level of uncertainty of presence/not detected for a relatively rare and elusive species.

\section{Small mammal capture rate}

At both mitigation sites, Deer Mice (Peromyscus maniculatus), shrews (Sorex spp.), and voles (Microtus 
TABLe 3. Capture rate of small mammals at the Pine Coulee Reservoir and the Twin Reservoir Valley project areas on 4-trap grids and traplines, southwestern Alberta, showing trap-nights (corrected trap-nights in parentheses).

\begin{tabular}{|c|c|c|c|c|c|c|}
\hline $\begin{array}{l}\text { Project area } \\
\text { and year }\end{array}$ & $\begin{array}{c}\text { Trapping dates } \\
\text { and configuration }\end{array}$ & $\begin{array}{c}\text { No. of } \\
\text { trap-nights }\end{array}$ & Species & $\begin{array}{c}\text { No. } \\
\text { captured }\end{array}$ & $\begin{array}{l}\text { Captu } \\
100 \text { tra }\end{array}$ & $\begin{array}{l}\text { are rate/ } \\
\text { ap-nights }\end{array}$ \\
\hline $\begin{array}{l}\text { Pine Coulee } \\
2005\end{array}$ & $\begin{array}{l}1 \text { to } 5 \text { November } \\
12 \text {-trap grids }\end{array}$ & $238(189)$ & $\begin{array}{l}\text { Deer Mouse } \\
\text { Shrew spp. } \\
\text { Vole spp. } \\
\text { Total }\end{array}$ & $\begin{array}{r}68 \\
3 \\
0 \\
71\end{array}$ & $\begin{array}{c}28.6 \\
1.3 \\
0 \\
29.8\end{array}$ & $\begin{array}{r}(36.0) \\
(1.6) \\
(37.6)\end{array}$ \\
\hline $\begin{array}{l}\text { Pine Coulee } \\
2006\end{array}$ & $\begin{array}{l}12 \text { to } 24 \text { October } \\
15 \text { 4-trap grids }\end{array}$ & $752(625.5)$ & $\begin{array}{l}\text { Deer Mouse } \\
\text { Shrew spp. } \\
\text { Vole spp. } \\
\text { Total }\end{array}$ & $\begin{array}{r}151 \\
3 \\
10 \\
164\end{array}$ & $\begin{array}{r}20.1 \\
0.4 \\
1.3 \\
21.8\end{array}$ & $\begin{array}{r}(24.1) \\
(0.5) \\
(1.6) \\
(26.2)\end{array}$ \\
\hline $\begin{array}{l}\text { Pine Coulee } \\
2007\end{array}$ & $\begin{array}{l}10 \text { to } 22 \text { October } \\
16 \text { 4-trap grids }\end{array}$ & $794(715.5)$ & $\begin{array}{l}\text { Deer Mouse } \\
\text { Shrew spp. } \\
\text { Vole spp. } \\
\text { Total }\end{array}$ & $\begin{array}{r}104 \\
2 \\
2 \\
108\end{array}$ & $\begin{array}{r}13.1 \\
0.2 \\
0.2 \\
13.6\end{array}$ & $\begin{array}{r}(14.5) \\
(0.3) \\
(0.3) \\
(15.1)\end{array}$ \\
\hline $\begin{array}{l}\text { Twin Valley } \\
2005\end{array}$ & $\begin{array}{l}8 \text { to } 12 \text { November } \\
84 \text {-trap grids }\end{array}$ & $138(116)$ & $\begin{array}{l}\text { Deer Mouse } \\
\text { Shrew spp. } \\
\text { Vole spp. } \\
\text { Total }\end{array}$ & $\begin{array}{r}34 \\
2 \\
1 \\
37\end{array}$ & $\begin{array}{r}24.6 \\
1.4 \\
0.7 \\
26.8\end{array}$ & $\begin{array}{r}(29.3) \\
(1.7) \\
(0.9) \\
(31.9)\end{array}$ \\
\hline $\begin{array}{l}\text { Twin Valley } \\
2008\end{array}$ & $\begin{array}{l}\text { Mosquito Creek trapline } \\
15 \text { to } 27 \text { October } \\
164 \text {-trap grids }\end{array}$ & $\begin{array}{c}62(44) \\
789(682)\end{array}$ & $\begin{array}{l}\text { Deer Mouse } \\
\text { Deer Mouse } \\
\text { Shrew spp. } \\
\text { Meadow Vole } \\
\text { Total }\end{array}$ & $\begin{array}{r}27 \\
103 \\
52 \\
15 \\
170\end{array}$ & $\begin{array}{r}43.5 \\
13.1 \\
6.6 \\
1.9 \\
21.5\end{array}$ & $\begin{array}{r}(61.4) \\
(15.1) \\
(7.7) \\
(2.2) \\
(24.9)\end{array}$ \\
\hline $\begin{array}{l}\text { Twin Valley } \\
2010\end{array}$ & $\begin{array}{l}15 \text { to } 27 \text { October } \\
16 \text { 4-trap grids }\end{array}$ & $825(717.5)$ & $\begin{array}{l}\text { Deer Mouse } \\
\text { Shrew spp. } \\
\text { Meadow Vole } \\
\text { Total }\end{array}$ & $\begin{array}{r}101 \\
52 \\
21 \\
174\end{array}$ & $\begin{array}{r}12.2 \\
6.3 \\
2.5 \\
21.1\end{array}$ & $\begin{array}{r}(14.1) \\
(7.2) \\
(2.9) \\
(24.2)\end{array}$ \\
\hline & Agriculture edge trapline & $102(69.5)$ & $\begin{array}{l}\text { Deer Mouse } \\
\text { Shrew spp. } \\
\text { Meadow Vole } \\
\text { Total }\end{array}$ & $\begin{array}{r}51 \\
2 \\
1 \\
54\end{array}$ & $\begin{array}{r}50.0 \\
2.0 \\
1.0 \\
52.9\end{array}$ & $\begin{array}{r}(73.4) \\
(2.9) \\
(1.4) \\
(77.7)\end{array}$ \\
\hline
\end{tabular}

spp.) were captured. In the composite sample trapped for all years (2005-2007) at Pine Coulee Reservoir, 94\% were Deer Mice, while shrews and voles were captured in nearly equal small percentages $(2 \%$ and $4 \%$, respectively). At Twin Valley Reservoir, excluding trap line captures, $62 \%$ of captures were Deer Mice, while $28 \%$ were shrews and $10 \%$ were voles. We did not individually identifying the shrews and voles in all years; however, the species that could be expected in these study areas include Cinereus Shrew (Masked Shrew) (Sorex cinereus), Prairie Shrew (Sorex haydeni), Dusky Shrew (Sorex monticolus), Meadow Vole (Microtus pennsylvanicus), and Sagebrush Vole (Lemmiscus curtatus) (Smith 1993).

The highest capture rate for Deer Mice was at Twin Valley Reservoir, along the fenceline separating the grain crop from mitigation land (50.0/100 trap-nights) (73.4/100 corrected trap-nights) and within the riparian zone of Mosquito Creek in 2005 (43.5/100 trapnights) (61.4/100 corrected trap-nights) (Table 3$)$. The capture rate along traplines in these two ecotones was 3 to 4 times higher than the capture rates on grids within tracts of relatively homogenous habitat.
On live trap grids, the capture rate of Deer Mice was highest during 2005 in both project areas, but somewhat higher at Pine Coulee Reservoir than at Twin Valley Reservoir (28.6/100 trap-nights (36.0/100 corrected trap-nights) at Pine Coulee Reservoir and 24.6/ 100 trap-nights (29.3/100 corrected trap-nights) at Twin Valley Reservoir) (Table 3).

During more intensive trapping effort at Pine Coulee Reservoir in 2006 and 2007 and at Twin Valley Reservoir in 2008 and 2010, the relative abundance of Deer Mice in both areas did not differ significantly between years $(20.1 / 100$ trap-nights $(24.1 / 100$ corrected trapnights) versus 13.1/100 trap-nights (14.5/100 corrected trap-nights $))$ at Pine Coulee Reservoir $\left(F_{55,55}=0.90\right.$, $\left.P=0.35, t_{110}=1.82, \mathrm{P}=0.07\right)$; and $13.1 / 100$ trapnights (15.1/100 corrected trap-nights) versus 12.2/100 trap-nights (14.1/100 corrected trap-nights)) at Twin Valley Reservoir, $t_{63}$ (paired) $=0.42, P=0.68$ ).

In temperate ecosystems, small mammals have been identified as universal prey, captured by virtually all carnivores and birds of prey (Gliwicz and Taylor 2002). Small mammals are important prey for the Long-tailed Weasel (Quick 1951; Simms 1979; Fagerstone 1999). 
However, larger prey species of the Long-tailed Weasel, such as Richardson's Ground Squirrel (Urocitellus richardsonii) (formerly Spermophilus richardsonii) and the Northern Pocket Gopher (Thomomys talpoides), were not sampled.

\section{Discussion}

We provide the first estimates of relative abundance of the Long-tailed Weasel in Alberta.

The relative abundance of Long-tailed Weasels on mitigation land at Pine Coulee Reservoir in southwestern Alberta was similar to, if not somewhat higher than, most other areas in Canada (Manitoba and Ontario) and the United States (Illinois and Indiana). Simms (1979) estimated the relative abundance of Long-tailed Weasels in four areas of southern Ontario using individual captures per 100 trap-nights: 1.03/100 trapnights on a $100-\mathrm{m}$ trap grid in Point Pelee National Park in southwestern Ontario; 0.06/100 trap-nights on a $100-\mathrm{m}$ trap grid in the Boyd Conservation Area and 0.28/100 trap-nights on a 100-m trapline in Duffin's Creek Conservation Area; and 0.08/100 trap-nights on a 100-m trapline in Algonquin Provincial Park in south-central Ontario. In southern Manitoba, Gamble (1980) reported 22 individuals captured during 21275 trap-nights, for a relative abundance of 0.10/100 trapnights (clustered trap arrangement using a variety of baits). Gehring and Swihart (2004) reported a relative abundance of 0.40 Long-tailed Weasels captured per 100 trap-nights (22 captures of 17 Long-tailed Weasels during 4256 trap-nights) in an agricultural landscape of west-central Indiana. Hajduk (2008) reported a relative abundance of 0.25 captures $/ 100$ trap-nights $(0.23$ individuals/100 trap-nights) in Pyramid State Park, Illinois.

Our results confirm that mitigation land surrounding Pine Coulee Reservoir provides suitable habitat for the Long-tailed Weasel. Our results also suggest that the Long-tailed Weasel population at Pine Coulee Reservoir remained stable during those years. If the population was stable, it also indicates the methodology was robust and provides support for our method as a means of long-term monitoring of relative abundance. Although the total length body measurements at Pine Coulee correspond to averages reported for Alberta by Smith (1993), the live weights that we obtained were at the lower end of the range reported for Alberta.

No Long-tailed Weasels were captured on mitigation land surrounding Twin Valley Reservoir. We conclude that Long-tailed Weasels may not be resident on the Twin Valley Reservoir mitigation lands. If Longtailed Weasels are resident there, they are less widely distributed and/or occur at lower density than at Pine Coulee Reservoir. This difference may be due to differences in one or more ecosystem components between the two project areas, and this suggests a fruitful avenue for further study.
If Long-tailed Weasels are present at Twin Valley Reservoir, they proved to be elusive and appeared to be considerably less abundant than at Pine Coulee Reservoir. The relative abundance of Deer Mice, shrews, and voles appeared to be similar at the two mitigation sites. This suggests that the relative abundance of small mammal prey that we examined did not explain the difference in relative abundance of Long-tailed Weasels.

We speculate that differences between the two mitigation sites with respect to abundance of large mammal prey, such as Richardson's Ground Squirrels and Northern Pocket Gophers, may have contributed to the observed difference in the abundance of Long-tailed Weasels. Also, differences in soil types, habitat types, land uses (cultivation and grazing history), and land use in the surrounding landscape were not measured at either mitigation site.

The basic ecological requirements of Long-tailed Weasels are food and cover resources, but Long-tailed Weasel populations also need space and protective corridors to allow for movement through and across the landscape. These unmeasured components suggest avenues for further study that may help explain differences in Long-tailed Weasel abundance in these twoareas of southwestern Alberta and provide further insight into their ecology in general.

\section{Acknowledgements}

We thank Sandy Black and Bob Peel of the Calgary Zoo for sharing their experience and information regarding the live capture and handling of Long-tailed Weasels. We thank Martin Urquhart for field assistance during 2007 and 2008, when DS was not available for fieldwork. John Mahoney, Senior Environmental Biologist with Water Operations Branch, Alberta Environment, administered the contract and provided direction and support. Clayton Weiss of Alberta Environment provided Figure 1. Wildlife \& Company Ltd. provided track tunnels in 2010. We thank Gilbert Proulx, Brian L. Horejsi, and Jason T. Fisher for constructive comments on an earlier draft of this manuscript. We also thank Jan Murie, Professor Emeritus, Department of Biological Sciences, University of Alberta, and Associate Editor David Nagorsen for constructive reviews. SNC Lavalin Environment, GEH's current employer, provided wage support for final manuscript editing.

\section{Documents Cited (marked * in text)}

Alberta Sustainable Resource Development. 2010. The General Status of Alberta Wild Species. http://www.srd .alberta.ca/FishWildlife/SpeciesAtRisk/GeneralStatusOf AlbertaWildSpecies/Default.aspx. (Accessed 14 May 2012).

Natural Regions Committee. 2006. Natural Regions and Subregions of Alberta. Compiled by D. J. Downing and W. W. Pettapiece. Publication no. T/852. Government of Alberta, Edmonton, Alberta. 
Golder Associates. 1995. Proposed Little Bow Project/Highwood Diversion Plan Environmental Impact Assessment, Volume 3, Environmental Assessment. Prepared for Alberta Public Works, Supply and Services, Civil Projects Division, Edmonton, Alberta, by Golder Associates, Calgary, Alberta.

\section{Literature Cited}

Beer, J. R. 1964. Bait preferences of some small mammals. Journal of Mammalogy 45: 632-634.

Dilks, P. J., C. F. J. O'Donnell, G. P. Elliott, and S. M. Phillipson. 1996. The effect of bait type, tunnel design, and trap position on stoat control operations for conservation management. New Zealand Journal of Zoology 23: 295-306.

Fagerstone, K. A. 1999. Long-tailed Weasel. Pages 555-558 in Chapter 42, Black-footed Ferret, Long-tailed Weasel, Short-tailed Weasel and Least Weasel. In Wild Furbearer Management and Conservation in North America. Second edition. Ontario Fur Managers Federation. CD-ROM.

Gamble, R. L. 1980. The ecology and distribution of Mustela frenata longicauda Bonaparte and its relationships to other Mustela spp. in sympatry. M.Sc. thesis, University of Manitoba, Winnipeg, Manitoba. 165 pages.

Gehring, T. M., and R. K. Swihart. 2004. Home range and movements of Long-tailed Weasels in a landscape fragmented by agriculture. Journal of Mammalogy 85: 79-86.

Gliwicz, J., and J. R. E. Taylor. 2002. Comparing life histories of shrews and rodents. Acta Theriologica 47, Supplement 1: 185-208.

Hajduk, L. I. 2008. Space use and habitat selection of Long-tailed Weasels (Mustela frenata) in southern Illinois. M.S. thesis, Southern Illinois University Carbondale, Carbondale, Illinois. 41 pages.

Kery, M. 2002. Inferring the absence of a species - a case study of snakes. Journal of Wildlife Management 66: 330 338 .

King, C. M. 1989. The Natural History of Weasels and Stoats. Comstock Publishing Associates, a division of Cornell University Press, Ithaca, New York. 253 pages.
King, C. M., and R. L. Edgar. 1977. Techniques for trapping and tracking stoats (Mustela erminae): a review, and a new system. New Zealand Journal of Zoology 4: 193-212.

Merritt, J. F. 2010. The Biology of Small Mammals. Johns Hopkins University Press, Baltimore, Maryland. 313 pages.

Nelson, L., Jr., and F. W. Clark. 1973. Correction for sprung traps in catch/effort calculations of trapping results. Journal of Mammalogy 54: 295-298.

Patric, E. F. 1970. Bait preferences of small mammals. Journal of Mammalogy 51: 179-182.

Proulx, G., and R. K. Dresher. 1993. Distribution of the Long-tailed Weasel, Mustela frenata longicauda, in Alberta as determined by questionnaires and interviews. Canadian Field-Naturalist 107: 186-191.

Quick, H. F. 1951. Notes on the ecology of weasels in Gunnison County, Colorado. Journal of Mammalogy 32: 281290.

Richter, S. M., and E. M. Schauber. 2006. Distribution of the Long-tailed Weasel (Mustela frenata) in Illinois. Transactions of the Illinois State Academy of Science 99: 153160 .

Robitaille, Jean-Francois, and M. Raymond. 1995. Spacing patterns of Ermine, Mustela erminea L., in a Quebec agrosystem. Canadian Journal of Zoology 73: 1827-1834.

Schlexer, F. V. 2008. Attracting animals to detection devices. Pages 263-292 in Noninvasive Survey Methods for Carnivores. Edited by R. A. Long, P. MacKay, W. J. Zielinski, and J. C. Ray. Island Press, Washington, D.C. 385 pages.

Simms, D. A. 1979. North American weasels: resource utilization and distribution. Canadian Journal of Zoology 57: 504-520.

Smith, H. C. 1993. Alberta Mammals: An Atlas and Guide. Provincial Museum of Alberta, Edmonton, Alberta. 238 pages.

Soper, J. D. 1964. The Mammals of Alberta. Hamly Press Ltd., Edmonton, Alberta. 410 pages.

Accepted 23 August 2012

Received 5 February 2013 